\title{
Protex 51FP as a starter for accelerating fish sauce fermentation from anchovy (Stolephorus commersonii)
}

\author{
Le Minh Chau ${ }^{1,3}$, Ho Thi Bich Ngoc ${ }^{1}$, Claire Donnay-Moreno², Sandrine Bruzac², Jean-Pascal Bergé ${ }^{3}$, \\ Vu Thi Hanh ${ }^{4 *}$
}

${ }^{1}$ Thai Nguyen University of Agriculture and Forestry, Quyet Thang commune, Thai Nguyen city, Vietnam, ${ }^{2} I F R E M E R$, street l'île d'Yeu, BP 21105, 44311 Nantes city, France, ${ }^{3}$ IDMer, 2 rue Batelière 56100 Lorient, France, ${ }^{4}$ Faculty of Food Science and Technology, Vietnam National University of Agriculture, Gia Lam district, Hanoi capital, Vietnam

\section{A B S T R A C T}

In this 180-day study, commercial Protex 51FP enzyme effects as a starter culture on anchovy fish sauce fermentation were investigated. Three fish source fermentation groups, including a control group (the anchovy with $25 \%$ of salt addition), E group (the anchovy with $25 \%$ of salt and $1 \%$ of Protex 51FP addition), and E (-s) group (the anchovy with $1 \%$ of Protex 51 FP and after 6 hours with $25 \%$ of salt), were compared. The fish sauce fermentation groups were sampled, packed into glass jars (10 liters), and covered by a lid at ambient temperature $\left(22-30^{\circ} \mathrm{C}\right)$ for 180 days. Three commercial fish sauces were also included as nutritional references. The results showed that the addition of Protex 51FP achieved positive results of total nitrogen content and amino acids compared to the control samples $(\mathrm{p}<0.05)$. These values were competitive with commercial product figures. Total amino acids in $8000 \mathrm{mg} / 100 \mathrm{ml}$ fish sauce were significantly higher than those in the control. There were rich in essential amino acids $(41-43 \%)$ and small peptides $(13 \%$ peptides with a molecular weight below $200 \mathrm{Da}, 32-39 \%$ peptides with a molecular weight below $130-200 \mathrm{Da}$, and $25-28 \%$ of peptides with a molecular weight below $200-360 \mathrm{Da})$. Compared with traditional methods, the addition of Protex 51FP $(p<0.05)$ could improve the quality of fish sauce and obtain greater nutritional values. In all experiments, the color of adding-enzyme samples was darker than that of the traditional products, and the smell of these samples (including traditional methods) was not as quite strong as commercial products.

Keywords: Fish sauce; Protex 51FP; Fermentation; Anchovy

\section{INTRODUCTION}

Fish sauce is produced in most Asian countries (Park et al., 2001). Each country has its own unique taste of fish source depending on the nutritional value and sensory quality. Manufacturing methods are often standardized within regions or villages, but they are varying due to local customs and fish species used. There are many different names for fish sauce in Southeast Asia such as Bubu (Malaysia), nam-pla, Kapi (Thailand), nuoc-mam (Vietnam), Ngam-pya-ye (Myanmar), Patis (Philippines), Padec (Laos), Shotturu (Japan), traces (Indonesia) (FAO and WHO, 2007). In general, fish is washed, mixed with salt following a ratio ranging from 2:1 to $3: 1$, and fermented at room temperature for 5 - 24 months depending on the production area (Lopetcharat et al., 2015; Park et al., 2001). Fukami et al. (2002) reported that fish sauce is basically produced from a mixture of fish and salt (3:1) that has been allowed to ferment for a period of up 6 months at a temperature of $30-35^{\circ} \mathrm{C}$. Although the high salty concentration is a potential condition for the inhibition of hydrolytic activity and the commercial supplement enzyme activity, it is needed to prevent deterioration from the mixture of fermented fish (Aspmo et al., 2005). The manufacturing process of fish sauce can be shortened by promoting fish hydrolysis from external protease sources such as papain, bromelain (Beddows and Ardeshir, 1979), or microorganisms such as Bacillus licheniformis RKK-04 (Toyokawa et al., 2010), Tetragenococcus balophilus (Udomsil et al., 2011), Staphylococcus carnosus and Bacillus amyloliquefaciens (Zaman et al., 2011). It was reported that spleen proteinase (spleen of Skipjack tuna) is also a potential novel enzyme for the acceleration of fish sauce production (Zaman et al., 2011). Youngsawatdigul et al. (2007) reported that the addition of starter culture reduced the fermentation time by $40 \%$. Gupta et al. (2002) suggested that the proteases from microbial sources are

Corresponding author:

Vu Thi Hanh, Faculty of Food Science and Technology, Vietnam National University of Agriculture, Gia Lam district, Hanoi capital, Vietnam.

E-mail: hanhvt@vnua.edu.vn 
preferred than from plant or animal sources, as they can meet the increasing demand and possess almost all the characteristics desired for various biotechnology industries. Ooshiro et al. (1981) reported that the commercial enzyme of papain increased the fermentation rate of fish sauce at various operating conditions and gave high contents of total soluble nitrogen, amino-type nitrogen, and volatile base nitrogen. However, it still remains unclear whether the commercial enzymes might influence the degree of hydrolysis during the fish fermentation time. Taking these into account, in the current study, we investigated the effect of the Protex 51FP enzyme on the degree of hydrolysis during the fish sauce fermentation time and the sensory and nutritional quality of fish sauce products.

\section{MATERIALS AND METHODS}

\section{Materials}

Anchovies (Stolephorus commersonii) were selected in the Nha Trang sea, Vietnam, and then transferred to the laboratory of Nha Trang University, Vietnam within an hour. After that, they were crushed and stored at $-20^{\circ} \mathrm{C}$ until analysis.

The Protex 51FP enzyme was provided by Genencor International (Lieben, The Netherlands). This is an endo/ exo-peptidase complex derived from a selected strain of Aspergillus oryzae (EC 3.4.23.18). The activity of Protex 51FP enzyme is effective in the temperature range of $25-60^{\circ} \mathrm{C}$.

Commercial fish sauces were bought from the local supermarket in Nha Trang, Vietnam. There were three typical brands including one Vietnamese brand classified as the first-class ones (Phu Quoc, Ca Com 60) and two classified as second class ones (Ca Com 30 from Vietnam and Con Ca from Thailand) (TCVN 5107-2018).

\section{Chemicals and reagents}

Sodium hydroxide $(\mathrm{NaOH})$, sodium chloride $(\mathrm{NaCl})$, 1-Fluoro - 2, 4 dinitrobenzene (DNFB), Sodium Tetraborate decahydrate $\left(\mathrm{B}_{4} \mathrm{NaO}_{7} \cdot 10 \mathrm{H}_{2} \mathrm{O}\right)$, and Glycine were purchased from Sigma-Aldrich. Hydrochloric acid $37 \%$ ( $\mathrm{HCl}$ ) was obtained from Merck, and hydrochloric acid $1 \mathrm{~N}(\mathrm{HCl})$ was purchased from Carlo Erba Reactifs - SDS. All other reagents were of analytical reagent grade and were used without further purification.

\section{Fish sauce fermentation}

The anchovies were first defrosted at room temperature in a plastic package and then $5 \mathrm{~kg}$ of fish mixed with $20 \%$ water (w/w) was used for each experiment. Three fish sauce fermentation groups were carried out as follow: the samples with $25 \%$ of salt (control as traditional fish sauce); the samples with $25 \%$ of salt and $1 \%$ of Protex $51 \mathrm{FP}(\mathrm{E})$; and samples with $1 \%$ of Protex 51FP to hydrolyze partially before adding $25 \%$ of salt at $6^{\text {th }}$ hours due to considering the activity of Protex 51FP affected by high salt content (Aspmo et al., 2005). Each fermentation group was carried out in triplicate and packed into glass jars (10 liters), covered by a lid, and kept for six months (180 days) of fermentation at ambient temperature $\left(22-30^{\circ} \mathrm{C}\right)$.

\section{Analysis of nitrogen content}

Total nitrogen (TN) was determined by the Kjeldahl method (AOAC, 2000). Ammonia nitrogen (AN) was also determined by the Kjeldahl method without any mineralization step. Formaldehyde nitrogen (FN) content, a convenient index of the degree of protein hydrolysis, was determined by the method Sorensen (Jodidi, 1926). Amino nitrogen was calculated as the difference between formol and ammonia nitrogen contents (Codex standard 302-2011). All those nitrogen contents were expressed in gram nitrogen/L.

\section{Analysis of salt content}

The salt content was measured by the method of AOAC (2000). Briefly, $20 \mathrm{~mL}$ samples were diluted with $180 \mathrm{ml}$ of distilled water, and then $1 \mathrm{~mL}$ of diluted sample was mixed with $10 \mathrm{~mL}$ of $0.1 \mathrm{~N} \mathrm{AgNO}_{3}$ and $10 \mathrm{~mL}$ of $\mathrm{HNO}_{3}$. The mixture was boiled gently on a hot plate until completely dissolved except $\mathrm{AgCl}_{2}$ (around $10 \mathrm{~min}$ ), cooled under a water tap, and then added to $50 \mathrm{ml}$ of distilled water and $5 \mathrm{ml}$ of ferric alum indicator. Finally, the mixture was titrated with standardized $0.1 \mathrm{~N} \mathrm{KSCN}$ until the solution became permanent light brown and the percentage of salt was then calculated as:

$$
\frac{0.00585 \times \mathrm{A} \times \mathrm{F} \times 1000}{\mathrm{~A}}
$$

0. 00585 represents the amount (in grams) of $\mathrm{NaCl}$ equivalent to $1 \mathrm{ml}$ of $0.1 \mathrm{~N} \mathrm{AgNO}_{3}$

A: Volume of $\mathrm{AgNO}_{3} 0.1 \mathrm{~N}$ used in the titration (ml)

F: dilution coefficient

V: diluted sample volume used for titration.

\section{pH value}

The $\mathrm{pH}$ value of fish sauce was determined by direct measurement using the electronic $\mathrm{pH}$ meter (Codex standard 302-2011).

\section{Analysis of amino acid composition}

The amino acid composition was determined using the EZ: faast ${ }^{\mathrm{TM}}$ procedure (Phenomenex, USA) as previously described (Kechaou et al., 2009). Namely, the samples were hydrolyzed by concentrated $\mathrm{HCl}$ and dried before derivatization. Derivatives were then injected and separated 
by gas chromatography. The amino acids were quantified by GC-FID (Perkin Elmer Autosystem XL) by their response factor relative to the internal standard norvaline.

\section{Molecular mass distribution of peptides}

The molecular mass distribution of peptides into the fish sauces was analyzed by gel filtration chromatography (Thi et al., 2011). Namely, the molecular mass fractions were separated using a high-performance liquid chromatography (HPLC) system equipped with a size exclusion column (Superdex Peptide 10/300 GL, GE Healthcare UK Ltd, Chalfont, UK). The mobile phase consisted of water with trifluoroacetic acid $0.1 \%$ and acetonitrile $0.5 \%(70: 30)$ at a flow rate of $0.5 \mathrm{~mL} / \mathrm{min}$. Chromatography was monitored by measuring the absorbance at $214 \mathrm{~nm}$. The column was calibrated with standards: ribonuclease A(13700 Da), aprotinin $(6500 \mathrm{Da})$, renin $(1760 \mathrm{Da})$, vasopressine (1084 $\mathrm{Da})$, and leucine $(294 \mathrm{Da})$. The molecular mass ranges of the different fractions were based on the retention times of the collected fractions and determined from a standard curve.

\section{Sensory evaluation}

After 6 months, samples were subjected to a blind sensory evaluation by a 5 -member panel. Based on standards of traditional products and strict consumer acceptance, 13 parameters related to flavor and color (transparency, yellow, brown, red, black, ammonia, acrid, cook, putrid, salt, sweet, umami, and bitter) were assessed using a 100-point quality scale with intensity descriptors at the endpoints (1, low; 100, high). A $20 \mathrm{~mL}$ of samples were filled into a glass cup covered with lids and kept at room temperature (approximately $25^{\circ} \mathrm{C}$ ) for $30 \mathrm{~min}$ before sensory evaluation. Color and transparency were first estimated, then the panelists have qualified the odor by opening the lid and sniffing. At least the flavor preference was assessed by tasting approximately $0.5 \mathrm{~mL}$ of fish sauce samples with an intermediate rinsing with water among each sauce.

\section{Statistical analysis}

The values are presented as means \pm SD. Differences between group means were estimated using a one-way analysis of variance followed by tests in Minitab 16 software (Minitab Inc., P.A.). A P-value of $<0.05$ was significantly considered.

\section{RESULTS AND DISCUSSION}

\section{Total nitrogen content}

There is a clear evidence that the total nitrogen content (TN) of a fish sauce is one key quality parameter used to establish the classification and commercial value of the product (Lopetcharat and Park, 2002). In this study, we found that TN increased rapidly within the first month $(p<0.05)$ with around $50 \%$ of augmentation for the control group and $80 \%$ for the fermentation group with the additional enzyme (Fig. 1a). Thereafter more moderate increases were observed with even a plateau reached after 120 days for the control group and the samples with enzyme and salt simultaneously (E) ( $p>0.05)$. Such shapes of evolution on a six-month fermentation basis have been previously observed despite different
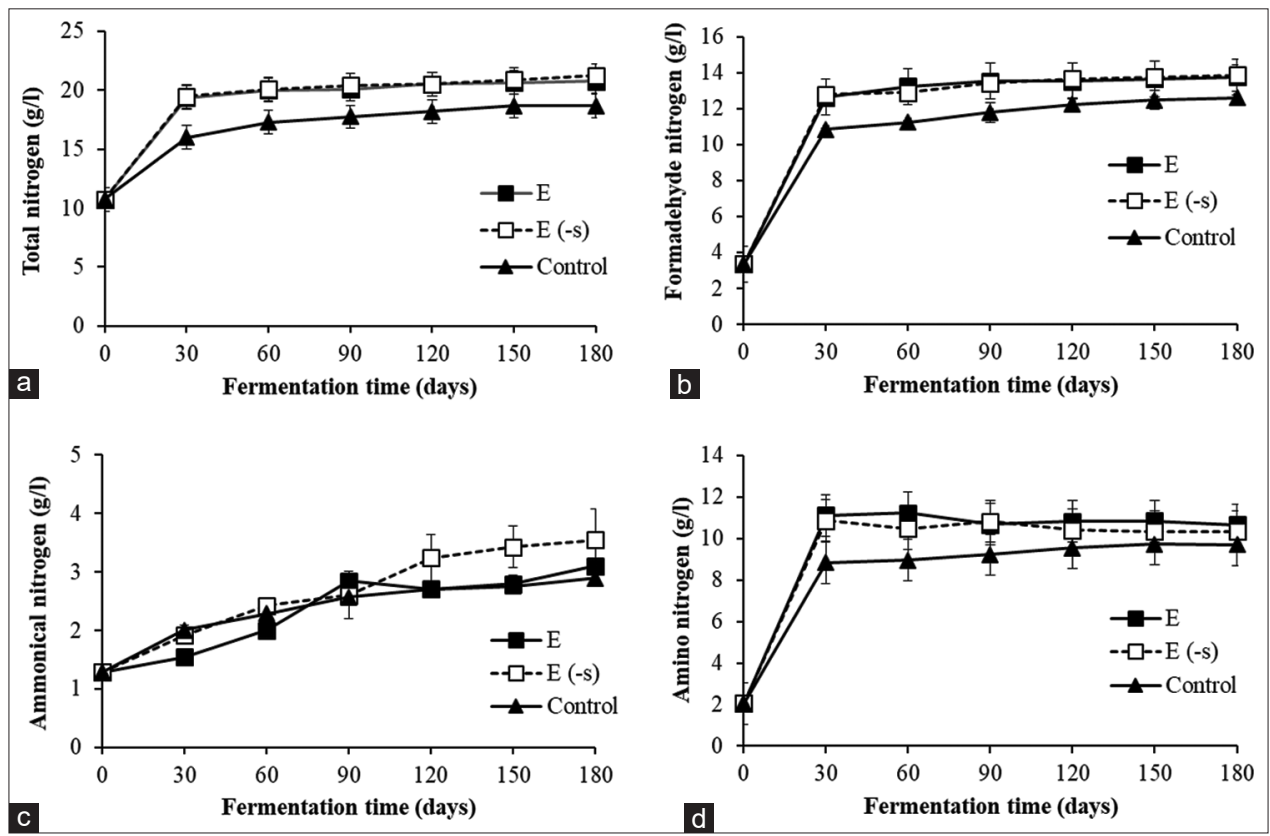

Fig 1. The values of total nitrogen (a), formaldehyde nitrogen (b), ammonia nitrogen (c) and amino nitrogen (d) in the fermentation process of fish sauce. Data as mean \pm SD. 
experimental conditions (Brililantes et al., 2002; Taira et al., 2007; Klomklao et al., 2006). The addition of Protex 51FP into the media has clearly enhanced TN, particularly in the initial stage of the fermentation with, in the end, more than $10 \%$ of additional TN compared to the control group (Table 1), according to previous studies that the protease was supplemented (Nakano et al., 1986; Guevara et al., 1972.; Ooshiro et al., 1981; Raksakulthai et al., 1986). This was possibly due to the greater degree of hydrolysis. As total nitrogen in fish sauce is mainly from protein and non-protein compounds (free amino acids, nucleotides, peptides, ammonia, urea, and TMAO (Klomklao et al., 2006). However, whatever the samples, no significant differences were observed for TN between sauces with Protex 51FP (E and E (-s)) illustrating the inefficiency of salt addition delay on this parameter. Those results showed that, even in a highly saline environment and low temperature $\left(\leq 30^{\circ} \mathrm{C}\right)$, Protex $51 \mathrm{FP}$ was useful to accelerate anchovy liquefaction, particularly during the first month of the fermentation process.

\section{Formaldehyde nitrogen}

The changes in formaldehyde nitrogen $(\mathrm{FN})$ were similar to the changes in total nitrogen (Fig. 1b). Indeed, in all the samples, a rapid increase was observed within the first month $(+220 \%$ for the control and $+280 \%$ for the sauces with Protex 51FP). Thereafter moderate increases occurred with a plateau reached after 150 days in all the samples ( $p$ $>0.05$ ). After 180 days of fermentation, the final contents in formaldehyde nitrogen differed between samples with or without enzyme as $12.6 \mathrm{~g} \mathrm{~N} / \mathrm{L}$ were found for control while 13.8 - $13.9 \mathrm{gN} / \mathrm{L}$ were quantified into samples containing Protex 51FP ( $\mathrm{p}<0.05)$. Formaldehyde reacts with amino acids and thus $\mathrm{FN}$ is useful for estimating total free amino acids. Therefore, this parameter is currently used as an index of protein hydrolysis degree (Chaveesuk et al., 1994). Our results also showed adding Protex 51FP together with or independent with salt increased protein

\begin{tabular}{|c|c|c|c|c|c|c|}
\hline \multirow{2}{*}{$\begin{array}{l}\text { Fish } \\
\text { sauce }\end{array}$} & \multicolumn{3}{|c|}{ Nitrogen (g/L) } & \multirow{2}{*}{$\begin{array}{c}\text { Moisture } \\
\text { (\%) }\end{array}$} & \multirow{2}{*}{$\begin{array}{l}\mathrm{NaCl} \\
(\mathrm{g} / \mathrm{L})\end{array}$} & \multirow[t]{2}{*}{$\mathrm{pH}$} \\
\hline & $\begin{array}{l}\text { Total } \\
\text { (TN) }\end{array}$ & $\begin{array}{c}\text { Amino } \\
\text { acid (AN) }\end{array}$ & $\begin{array}{l}\text { Ammonia } \\
\text { (AM) }\end{array}$ & & & \\
\hline$E$ & $20.77^{\mathrm{ab}}$ & $10.66^{a}$ & $3.10^{b}$ & 69.82 & 223.84 & 6.11 \\
\hline$E(-s)$ & $21.23^{a}$ & $10.34^{\mathrm{ab}}$ & $3.55^{a}$ & 66.46 & 218.53 & 6.07 \\
\hline Control & $18.67^{c}$ & $9.71 \mathrm{c}$ & $2.89^{c}$ & 71.19 & 231.24 & 6.82 \\
\hline $\begin{array}{l}\text { Phu } \\
\text { Quoc }\end{array}$ & 33.32 & 14.82 & 5.10 & 60.60 & 210.47 & 5.44 \\
\hline $\begin{array}{l}\mathrm{Ca} \\
\mathrm{Com} 60\end{array}$ & 30.80 & 13.17 & 4.75 & 63.58 & 197.80 & 5.25 \\
\hline $\begin{array}{l}\mathrm{Ca} \\
\mathrm{Com} 30\end{array}$ & 19.60 & 8.14 & 3.10 & 68.96 & 197.98 & 5.88 \\
\hline Con $\mathrm{Ca}$ & 19.32 & 7.86 & 2.68 & 72.07 & 202.78 & 5.11 \\
\hline
\end{tabular}

Data as mean \pm SD. Means without a common letter are significantly different; $P<0.05$ hydrolysis compared to control. This suggested that such an enzyme could help the conversion of insoluble nitrogen into soluble one, similar to other studies by Beddows and Ardeshir, 1979; Chaveesuk et al., 1994; Miayaki et al., 1979; Raksakulthai et al., 1986.

\section{Ammonia nitrogen}

The ammonia nitrogen content gives an indication regarding the breakdown of soluble proteins and peptides into volatile nitrogen and free amino acids (Chaveesuk et al., 1994; Lopetcharat and Park, 2002). As shown in Fig. 1c, the ammonia nitrogen content of fish sauces increased during the 6 months of fermentation. However, it reached a plateau for the control after 120 days $(p>0.05)$ and may be due to simultaneously added enzyme and salt (except the ending point), while at the opposite a constant increase was noticed for the experiments with Protex 51FP where salt addition was delayed $(p<0.05)$. After 180 days of fermentation, the maximum contents of ammonia nitrogen observed in samples were: $2.89 \mathrm{~g} / \mathrm{L}$ for control, $3.10 \mathrm{~g} / \mathrm{L}$ for sauce containing enzyme and salt since the beginning, and $3.55 \mathrm{~g} / \mathrm{L}$ for the sauce with enzyme but a delay of 6 hours for the salt addition (Table 1). Higher ammonia nitrogen contents were obtained when Protex 51FP was added, particularly when the salt supplement was postponed. Indeed, such enzymes may have played a role like the other internal fish enzymes on this parameter by increasing the proteolysis of proteins and peptides (Beddows et al., 1980). All the experiments were realized with $25 \% \mathrm{NaCl}$, thus the generation of ammonia and volatile compounds by spoilage microorganisms is unlikely as no apparent spoilage in fish sauce occurs above $10 \%$ $\mathrm{NaCl}$ (Beddows and Ardeshir, 1979). Previous studies suggested that the constant ammonia content after several days of fermentation could be due to a balance between formation and reaction with other compounds notably via the Maillard reaction and that color and flavor would be modified (Klomklao et al., 2006).

\section{Amino nitrogen}

The amino nitrogen (AN) was quantified based on the primary amino group. The amino nitrogen content of fish sauces during the 6 months of fermentation is presented in Fig. 1d. Globally, as in previous studies, similar patterns were observed for TN and AN suggesting that nitrogen compounds were hydrolyzed during the fermentation into amino acids (Ooshiro et al., 1981; Nakano et al., 1986; Klomklao et al., 2006). The addition of Protex 51FP into the media has clearly enhanced amino nitrogen content, particularly during the primary month of fermentation. However, there were slightly different contents of AN among all the experiments at the final fermentation time, and the AN content reached a plateau after 30 days in samples added Protex 51FP while it took 120 days in the 
control. Our results suggested that the addition of Protex 51FP has speeded up the process of anchovy liquefaction by increasing the proteolysis leading to higher contents in total nitrogen, formaldehyde nitrogen, and free amino nitrogen but with little differences regarding the amino nitrogen.

\section{Biochemical parameters}

The biochemical parameters in the fermented fish sauce were compared to those fermented with the addition of commercial Protex 51FP enzyme. After 6 months of fish sauce fermentation, there was not a statistically significant difference in TN content between $\mathrm{E}$ and $\mathrm{E}$ (-s). However, there was a statistically significant difference in TN content among three samples E, E (-s), and control as similar to the AN content (Table 1).

Among the commercial fish sauces, the values of TN and acid AN in Phu Quoc were higher than in Ca Com 60. These are two Vietnamese samples that have a high rank in the market. Another fish sauce sample from Vietnam was $\mathrm{Ca}$ Com 30 and it brought lower values which were the same in-sample Con Ca of Thailand. All fermented samples in our experiments had lower $\mathrm{TN}, \mathrm{AN}$, and ammonia nitrogen contents than Phu Quoc and Ca Com 60 but higher than the other two commercial samples.

Moisture in two fish sauces samples added Protex 51FP was lower than in the control sample. The highest value of moisture was obtained in the commercial fish sauce Con Ca $(72.07 \%)$ and control $(71.19 \%)$. Moisture in two commercial fish sauces (Phu Quoc and Ca Com 60) was lower. Park et al. (2002) showed that the average moisture was $65.8 \%$ for all commercial fish sauce samples, high in Laotian samples $(79.2 \%)$, and low in Vietnamese and Thailand samples (61.4\% and $63.7 \%$, respectively). However, Park et al. (2002) reported that the moisture of fish sauce was only $58.4 \%$.

Table 1 showed that all fish sauce samples had $\mathrm{pH}$ values ranging from $5.11-6.82$. The $\mathrm{pH}$ values of three experimental fish sauces were higher than those of commercial fish sauces. Park et al., (2001) showed that the average $\mathrm{pH}$ of fish sauces in Asian countries ranged from 5.4 to 5.8 except products of Myanmar (6.23), Laotian (4.90), and Chinese (6.15). Zaman et al., (2011) reported that the $\mathrm{pH}$ value reached $7.11-7.48$ after 120 days of fermentation. The high $\mathrm{pH}$ of our samples may reflect bacterial activity during fermentation (Park et al., 2001).

\section{Amino acid profiles and molecular weight}

As shown in Table 2, the results showed that the total amino acid content of both $\mathrm{E}$ and $\mathrm{E}(-\mathrm{s})$ samples was higher than that of the control. Total amino acid contents of experimental fish sauces $(7880-8385 \mathrm{mg} / 100 \mathrm{~mL})$ were lower than those of Phu Quoc $(15475 \mathrm{mg} / 100 \mathrm{~mL})$ and Ca Com $60(13040 \mathrm{mg} / 100 \mathrm{~mL})$ but higher than those of Ca Com 30 (6511 mg/100mL) and Con Ca (4433 mg/100mL). The results showed that fish sauce samples treated with Protex 51FP obtained isoleucine, leucine, lysine, valine, alanine, glutamic, glycine, and serine contents higher than in the control sample. With commercial fish sauce, the value of essential amino acid was found from highest to lowest in Phu Quoc (4808 mg/100mL), Ca Com 60 (3746 mg/100mL), experimental samples (3119-3469 mg/100mL), and Con Ca (1935 mg/100mL), respectively. The percentage of essential amino acid to total amino acid was highest in commercial fish sauce Con Ca $(48.42 \%)$, followed by in our experimental samples (43.09 - 46.19\%), and lowest in commercial fish sauce Ca Com 60 (35.08\%). Ijong and Ohta (1995) reported that the total essential amino acids in baking samples ranged between 42.36 and $46.65 \mathrm{mg} / \mathrm{mL}$, they were lower than the Phu Quoc $(58.96 \mathrm{mg} / \mathrm{mL})$, but was higher than the other samples in our experiments $(34.60-37.78 \mathrm{mg} / \mathrm{mL})$. When compared to commercial fish sauce, we found that the total amino acid value was highest in Phu Quoc, Ca Com 60, value ranged from 15475 - $13040 \mathrm{mg} / 100 \mathrm{~mL}$. Group experimental fish sauce was smaller, it ranged from $8385-7880 \mathrm{mg} / 100 \mathrm{~mL}$. The lowest value was in Ca Com 30 (6511 mg/100mL) and Con Ca (4433 mg/100mL). Chaveesuk et al. (1994) also reported that the number of amino acids in the samples treated with enzymes added was higher than the control samples but lower than those of commercial products.

A study of the commercial fish sauce by Park et al. (2001) has announced that the total amino acid was highest in the Vietnamese samples followed by the Japanese and Thailand (6732-9826 mg/100mL). They were ranked "high-content" after it was the 'intermediate' group (China and Korea) and the "low-content" group (Myanmar and Laos). Fish sauces from these three countries showed high aspartate, glutamate, alanine, valine, lysine, and histidine values. Taira et al. (2007) also announced that total free amino acid content has reached over $6000 \mathrm{mg} / 100 \mathrm{~mL}$ at the end of fermentation, similar to the amino acid composition majority. With a fermented product fish sauce with bacteria, the total amino acid contents were in the same range of $9000-9500 \mathrm{mg} / 100 \mathrm{~mL}$, but the time of fermentation was up to 12 months (Yongsawatdigul et al., 2007). However, it was reported that fish sauce treated with hepatopancreas and fermented for 13 months obtained lower total amino acid contents than in fish sauce treated with Protex 51FP (Raksakulthai et al., 1986).

In two commercial samples of Phu Quoc and Ca Com 60, there were greater amount of lysine $(871-1082 \mathrm{mg} / 100 \mathrm{~mL})$, 
Table 2: Total amino acid content of fish sauce samples and commercial fish sauce

\begin{tabular}{|c|c|c|c|c|c|c|c|}
\hline \multirow{3}{*}{$\begin{array}{l}\text { Amino acid } \\
(\mathrm{mg} / 100 \mathrm{~mL})\end{array}$} & \multirow{2}{*}{\multicolumn{3}{|c|}{ Experimental sauces }} & \multicolumn{4}{|c|}{ Commercial fish sauce } \\
\hline & & & & \multicolumn{3}{|c|}{ Vietnam } & \multirow{2}{*}{$\begin{array}{c}\text { Thailand } \\
\text { Con } \mathrm{Ca} \\
\end{array}$} \\
\hline & $E$ & $E(-s)$ & Control & Phu Quoc & Ca Com 60 & Ca Com 30 & \\
\hline Isoleucine & 658.2 & 565.18 & 548.8 & 582.01 & 477.04 & 380.27 & 380.55 \\
\hline Leucine & 811.11 & 753.57 & 698.83 & 524.76 & 381.63 & 380.27 & 536.67 \\
\hline Lysine & 452.1 & 578.88 & 331.65 & 1082.91 & 871.67 & 351.3 & 240.69 \\
\hline Methionine & 279.24 & 246.62 & 240.84 & 233.76 & 143.11 & 119.51 & 123.6 \\
\hline Phenylalanine & 352.37 & 376.78 & 398.77 & 529.53 & 429.33 & 220.92 & 191.9 \\
\hline Threonine & 73.13 & 321.98 & 533 & 1097.23 & 836.98 & 278.87 & 217.92 \\
\hline Valine & 708.06 & 698.76 & 647.5 & 1178.33 & 1032.13 & 459.95 & 318.75 \\
\hline Histidine & 126.32 & 236.35 & 240.84 & 667.88 & 403.31 & 134 & 136.61 \\
\hline Essential amino acids (EAA) & 3460.53 & 3778.12 & 3640.21 & 5896.4 & 4575.2 & 2325.1 & 2146.69 \\
\hline Alanine & 1333.02 & 1404.38 & 947.56 & 1865.28 & 1504.83 & 604.82 & 383.8 \\
\hline Aspartic & 468.72 & 482.97 & 686.98 & 1703.09 & 1478.81 & 517.9 & 354.53 \\
\hline Glutamic & 1323.05 & 1219.41 & 1172.61 & 2418.67 & 2172.68 & 2089.69 & 933.49 \\
\hline Glycine & 791.17 & 842.63 & 714.62 & 1607.68 & 1890.79 & 503.41 & 305.74 \\
\hline Hydroxyproline & 26.59 & 34.25 & 27.64 & 100.18 & 69.39 & 25.35 & 22.77 \\
\hline Proline & 73.13 & 321.98 & 533 & 1097.23 & 836.98 & 278.87 & 217.92 \\
\hline Serine & 531.88 & 524.07 & 481.68 & 1097.23 & 871.67 & 289.73 & 182.14 \\
\hline Tyrosine & 53.19 & 68.51 & 173.72 & 758.52 & 459.69 & 141.24 & 97.58 \\
\hline 2-Cysteine & 23.27 & 17.13 & 23.69 & 19.08 & 8.67 & 7.24 & - \\
\hline Non-essential amino acids & 4570.82 & 4607.05 & 4240.34 & 9579.26 & 8465.21 & 4186.62 & 2286.55 \\
\hline TOTAL & 8031.37 & 8385.17 & 7880.57 & 15475.68 & 13040.4 & 6511.71 & 4433.25 \\
\hline$\% \mathrm{AAE} /$ total & 43.09 & 45.06 & 46.19 & 38.1 & 35.08 & 35.71 & 48.42 \\
\hline
\end{tabular}

valine $(1032-1178 \mathrm{mg} / 100 \mathrm{~mL})$, phenylalanine (429$529 \mathrm{mg} / 100 \mathrm{~mL})$, histidine (403-667mg/100mL), glutamic (2172-2418 mg/100mL), glycine (1607-1890 mg/100mL), alanine $(1504-1856 \mathrm{mg} / 100 \mathrm{~mL})$, aspartic (1478$1703 \mathrm{mg} / 100 \mathrm{~mL})$, serine $(871-1097 \mathrm{mg} / 100 \mathrm{~mL})$, proline (836-1097 mg/100mL), tyrosine (495-758 mg/100mL) than our experimental samples. However, the value of the above-mentioned amino acid in our prototype higher than commercial fish sauce remaining, a few amino acids such as isoleucine, lysine, methionine, threonine, cysteine-cysteine in experimental samples were higher than in commercial samples. These results were in agreement with the amino acid profiles of fish sauce reported by e other studies (Taira et al., 2007; Chaveesuk et al., 1994; Park et al., 2001; Yongsawatdigul et al., 2007).

Glutamic, glycine, aspartic, alanine, lysine, valine were predominant amino acids in commercial samples, while there were more common amino acids glutamic, alanine, glycine, leucine, valine, isoleucine in experiments samples. Park et al. (2002) reported that together with glutamic acid and alanine, then there were all threonine, tyrosine, histidine, and methionine to be the taste-active components providing the characteristic taste of the fish sauce.

It has been demonstrated that bioactive peptides consisting of 2 to 9 amino acids are essential in the prevention of lifestyle-related diseases (Yoshikawa et al., 2000). In this current study, we investigated the molecular weight distribution of peptides in the experimental fish sauces for the first time (Table 3). The results showed that the experimental fish sauces had $13 \%$ of peptides with a molecular weight below $130 \mathrm{Da}, 32-39 \%$ of peptides with a molecular weight of $130-200 \mathrm{Da}$, and $25-28 \%$ of peptides with a molecular weight of 200-360 Da. Two fish sauce samples E and E (-s) added Protex 51FP had 52\% of peptides with a molecular weight below $200 \mathrm{Da}$ while the control and commercial samples only had $42-47 \%$ of peptides with a molecular weight below $200 \mathrm{Da}$. This result showed the capability to form the low molecular weight peptides of Protex 51FP.

The majority of peptides in experimental and commercial fish sauces had a molecular weight below $600 \mathrm{Da}$ (91-95\%). There was not any peptide with a molecular weight above $1300 \mathrm{Da}$ in the commercial fish sauces Phu Quoc and Ca Com 60. It was suggested that protease might hydrolyze protein into small peptides with a low molecular weight when fermented for a long time in these two commercial fish sauces.

\section{Sensory evaluation of fish sauce}

The sensory profiles of fish sauce samples based on the quantitative descriptive analysis test-thirteen attributes were shown in Fig. 2. The scores for transparency were highest among all samples. The score for salt was high but the score for bitterness was low. The scores for putrid, cook, acrid, ammonia were low among all samples, indicating no apparent spoilage occurred during fermentation. 


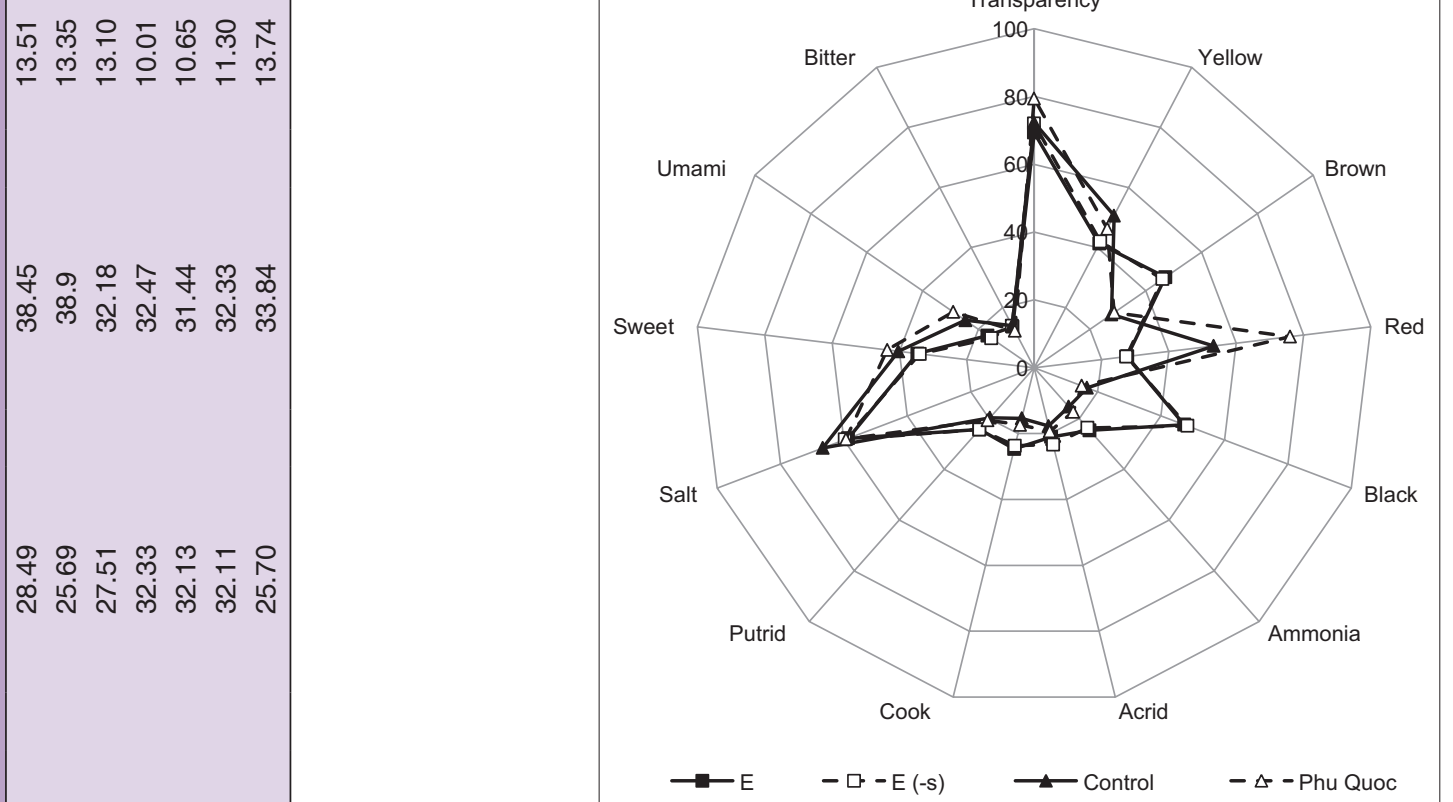

ป I

எ

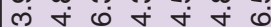

ヘ $0 \div \div 0$

일

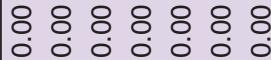

00000000

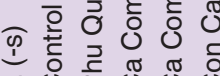

山
Fig 2. Star diagrams of sensory properties of fish sauces obtained from experiment and the commercial

There was a similar sensory quality between $\mathrm{E}$ and $\mathrm{E}(-\mathrm{s})$ both treated with Protex 51FP enzyme. They had higher scores for brown and black than the control and Phu Quoc. However, the scores for red in these two fish sauces were lower than those in the control and Phu Quoc.

Ijong and Ohta (1995) suggested that flavor development would be affected by salt concentration and that the flavor of Bakasang (Indonesia fish sauce) could be attributable to glutamic acid. However, in the current study, we found that there was a large amount of glutamic acid but the flavor was worse than commercial fish sauces. It was suggested that other components may be present in fish sauces.

Park et al., (2002) showed that eleven compounds including glutamic acid, aspartic acid, threonine, alanine, valine, histidine, proline, tyrosine, cystine, methionine, and pyroglutamic acid were identified to be the taste-active components. It was also reported that the most effective compound for creating the characteristic flavor of fish sauce was glutamic acid, followed by pyroglutamic acid and alanine.

\section{Yields of fish sauce}

In two samples with Protex 51FP, there was a difference only in the experiment process (Table 4). At E, salt was added in the beginning. At $\mathrm{E}(-\mathrm{s})$, salt was added after 6 hours since the experiment began. This action aimed to make better conditions for Protex 51FP to act its hydrolysis role. The obtained result showed that the total fish sauce of $\mathrm{E}(-\mathrm{s})$ was much more than $\mathrm{E}$ after 6 months. In the 
Table 4: The value of the fish sauce and nitrogen recovery

\begin{tabular}{lcccc}
$\begin{array}{l}\text { Fish } \\
\text { sauce }\end{array}$ & $\begin{array}{c}\text { Fish } \\
(\mathbf{k g})\end{array}$ & $\begin{array}{c}\text { Sauce } \\
\mathbf{( k g})\end{array}$ & $\begin{array}{c}\mathbf{g ~ N} \\
\text { recovery }\end{array}$ & $\begin{array}{c}\mathbf{g ~ N} / \mathbf{k g} \\
\text { fish }\end{array}$ \\
\hline $\mathrm{E}$ & 5 & $1.732 \pm 0.034$ & $50.18 \pm 0.98$ & $10.04 \pm 0.2$ \\
$\mathrm{E}(-\mathrm{s})$ & 5 & $2.016 \pm 0.038$ & $60.69 \pm 1.16$ & $12.14 \pm 0.23$ \\
Control & 5 & $0.943 \pm 0.018$ & $29.01 \pm 0.56$ & $5.80 \pm 0.11$ \\
\hline
\end{tabular}

Data as mean \pm SD.

case of analyzing the number of game nitrogen out of $1 \mathrm{~kg}$ fish sauce in $5 \mathrm{~kg}$ material, we found that sample $\mathrm{E}(-\mathrm{s})$ was higher than $\mathrm{E}$ and control sample $(\mathrm{p}<0.05)$. Adding Protex 51FP made the amount of nitrogen from each kilogram material twice than traditional way and adding salt later than 6 hours also brought a better statistical result. In another way, it was economic. Ooshiro et al. (1981) reported that the addition of salt plus $24 \mathrm{~h}$ keeping at $50^{\circ} \mathrm{C}$ and mincing resulted that the highest yield in the volume of fish sauce was obtained. This study confirms that the presence of Protex 51FP the presence of Protex 51FP may improve both nutritionally and in terms of yield compared to the traditional method.

\section{CONCLUSIONS}

The addition of commercial Protex 51FP enzyme as a starter culture to the anchovy hydrolysate increased the degree of hydrolysis during 6-month fermentation. Total amino acid profiles of fish sauce, the percentage of the essential amino acids, and low molecular weight inoculated by Protex 51FP were comparable with those of sample traditionally fermented. Samples inoculated by Protex 51FP have a darker color than the traditional products, and the smell of all the samples (including traditional methods) is less than commercial products. Protex 51FP could be a potential strain applied to accelerate fish sauce fermentation to increase the quality of the fish sauce products.

\section{FUNDING}

This work was financially supported by a research grant from the Ministry of Education and Training of Vietnam, The IFREMER (French Research Institute for the Exploitation of the Sea) in the Atlantic.

\section{CONFLICT OF INTEREST}

The authors declare no competing financial interest.

\section{Author's contributions}

Le Minh Chau performed the experiments, interpreted and analyzed data, and wrote the paper. Ho Thi Bich Ngoc, Claire Donnay-Moreno, Sandrine Bruzac, and Jean-Pascal Bergé interpreted and analyzed data and wrote the paper;
Vu Thi Hanh assisted in conducting the study, interpreted and analyzed data, and wrote the paper. All authors have read and approved the final manuscript to be published.

\section{REFERENCE}

AOAC. 2000. Official Method of Analysis of AOAC International 17. Association of official Analytical Chemists, Washington, DC, United States.

Aspmo, S. I., S. J. Horn and V. G. H. Eijsink. 2005. Enzymatic hydrolysis of Atlantic cod (Gadus morhua L.) viscera. Proc. Biochem. 40: 1957-1966.

Beddows, C. G. and A. G. Ardeshir. 1979. The production of soluble fish protein solution for use in fish sauce manufacture. J. Food Sci. Technol. 14: 603-612.

Beddows, C. G., A. G. Ardeshir and W. J. B. Daud. 1980. Development and origin of the volatile fatty acids in budu. J. Sci. Food Agric. 31: 86-92.

Brillantes, S., S. Paknoi and A. Totakien. 2002. Histamine formation in fish sauce. J. Food Sci. 67: 2090-2094.

Chaveesuk, R., J. P. Smith and B. K. Simpson. 1994. Production of fish sauce and acceleration of sauce fermentation using proteolytic enzymes. Aquat. Food Prod. Technol. 2 (3): 59-77.

Codex Standard 302-2011. 2011. Codex CXS 302-2011: Standards for Fish Sauce.

Guevara, G., V. C. Matias and P. O. Delta-Pena. 1972. Fish fermentation with the use of papain. Philippines J. Fish. 10: 30-38.

Gupta, R., Q. K. Beg and P. Lorenz. 2002. Bacterial alkaline proteases: Molecular approaches and industrial applications. Appl. Microbiol. Biotechnol. 59: 15-32.

Fukami, K., S. Ishiyama, H. Yaguramaki, T. Masuzawa, Y. Nabeta, K. Endo and M. Shimoda. 2002. Identification of distinctive volatile compounds in fish sauce. J. Agric. Food Chem. 50: 5412-5416.

FAO and WHO. 2007. Codex Alimentarius Commission CX/FFP 08/29/9. Joint FAO/WHO Food Standards Programme. Codex Committee on Fish and Fishery Products. World Health Organization, Geneva.

ljong, F. G. and Y. Ohta. 1995. Amino acid compositions of bakasang, a traditional fermented fish sauce from indonesia. LWT Food Sci. Technol. 28: 236-237.

Jodidi, S. L. 1926. The formol titration of certain amino acids. J. Am. Chem. Soc. 48: 751-753.

Kechaou, E. S., J. Dumay, C. Donnay-Moreno, P. Jaouen, J. P. Gouygou, J. P. Bergé and R. B. Amar. 2009. Enzymatic hydrolysis of cuttlefish (Sepia officinalis) and sardine (Sardina pilchardus) viscera using commercial proteases: Effects on lipid distribution and amino acid composition. J. Biosci. Bioeng. 107: 158-164

Klomklao, S., S. Benjakul, W. Visessanguan, H. Kishimura and B. K. Simpson. 2006. Effects of the addition of spleen of skipjack tuna (Katsuwonus pelamis) on the liquefaction and characteristics of fish sauce made from sardine (Sardinella gibbosa). Food Chem. 98: 440-452.

Lopetcharat, K., Y. J. Choi, J. W. Park, M. A. Daeschel, Y. J. Choi, J. W. Park, M. A. Daeschel, K. Lopetcharat, Y. J. Choi and J. W. Park. 2015. Fish sauce products and manufacturing: A review. Food Rev. Int. 9129: 37-41.

Lopetcharat, K. and J. W. Park. 2002. Characteristics of fish sauce made from pacific whiting and surimi by-products during fermentation stage. J. Food Sci. 67: 511-516. 
Miyazawa, K., C. V. Le, K. Ho and M. Fumio. 1979. Studies on fish sauce. J. Fac. Appl. Biol. Sci., Hiroshima Univ. 18: 55-63.

Nakano, T., H. Watanabe, M. Hata, D. V. Qua and T. Miura. 1986. An application of protease produced by a moderately; halophilic marine bacterium to fish sauce processing. Nippon Suisan Gakk. 52: 1581-1587.

Ooshiro, Z., T. Ok, H. Une, S. Hayashi and T. Itakura. 1981. Study on use of commercial proteolytic enzymes 1981. Mem. Fac. Fish. Kagoshima Univ. 30: 383-394.

Park, J. N., Y. Fukumoto, E. Fujita, T. Tanaka, T. Washio, S. Otsuka, T. Shimizu, K. Watanabe and H. Abe. 2001. Chemical composition of fish sauces produced in Southeast and East Asian countries. J. Food Compost. Anal. 14: 113-125.

Park, J. N., T. Watanabe, K. I. Endoh, K. Watanabe and H. Abe. 2002. Taste-active components in a Vietnamese fish sauce. Fish Sci. 68: 913-920.

Raksakulthai, N., Y. Z. Lee and N. F. Haard. 1986. Effect of enzyme supplements on the production of fish sauce from male capelin (Mallotus villosus). Can. Inst. Food Sci. Technol. J. 19: 28-33.

Taira, W., Y. Funatsu, M. Satomi, T. Takano and H. Abe. 2007.
Changes in extractive components and microbial proliferation during fermentation of fish sauce from underutilized fish species and quality of final. Fish. Sci. 73: 913-923.

TCVN 5107-2018. 2003. Vietnamese Standards for Fish Sauce.

Thi, H., M. Nguyen, K. Serigne, B. Sylla, Z. Randriamahatody, C. Donnay-Moreno, J. Moreau, L. T. Tran and J. P. Bergé. 2011. Enzymatic hydrolysis of yellowfin tuna. Food Technol. Biotechnol. 49: 48-55.

Toyokawa, Y., H. Takahara, A. Reungsang, M. Fukuta, Y. Hachimine, S. Tachibana and M. Yasuda. 2010. Purification and characterization of a halotolerant serine proteinase from thermotolerant Bacillus licheniformis RKK-04 isolated from Thai fish sauce. Appl. Microbiol. Biotechnol. 86: 1867-1875.

Udomsil, N., S. Rodtong, Y. J. Choi, Y. Hua and J. Yongsawatdigul. 2011. Use of tetragenococcus halophilus as a starter culture for flavor improvement in fish sauce fermentation. J. Agric. Food Chem. 59: 8401-8408.

Yoshikawa, M., H. Fujita, N. Matoba and Y. Takenaka. 2000. Bioactive peptides derived from food proteins preventing lifestyle-related diseases. Biofactors. 12: 143-146. 